\title{
ECONOMIC VALUE ADDED, MARKET VALUE ADDED, DAN KINERJA KEUANGAN TERHADAP RETURN SAHAM
}

\author{
RUTJI SATWIKO \\ VLADIMIR AGUSTO \\ Trisakti School of Management, JI. Kyai Tapa No. 20, Jakarta, Indonesia \\ rutj@stietrisakti.ac.id
}

\begin{abstract}
The research objective is to determine the variables that affect stock returns. The independent variables used in this study are economic value added, market value added, debt to equity ratio, price to book value, total assets turnover, return on equity, net profit margin, and earnings per share. The dependent variable in this study is stock returns. The population in this study were non-financial companies listed on the Indonesia Stock Exchange for 5 consecutive years, from 2013 to 2017. The sample selection method used was purposive sampling. The research sample is 52 non-financial companies listed on the Indonesia Stock Exchange. Hypothesis testing uses multiple regression models. The results indicate that economic value added, debt to equity ratio, total assets turnover, net profit margin, and earnings per share have no effect on stock returns. However, market value added and return on equity have a positive effect on stock returns. Meanwhile, price to book value has a negative effect on stock returns.
\end{abstract}

Keywords: Share return, economic value added, market value added, financial performance.

Abstrak: Tujuan penelitian adalah untuk menentukan variabel-variabel yang mempengaruhi return saham. Variabel independen yang digunakan dalam penelitian ini adalah economic value added, market value added, debt to equity ratio, price to book value, total assets turnover, return on equity, net profit margin, dan earnings per share. Variabel dependen dalam penelitian ini adalah return saham. Populasi dalam penelitian ini adalah perusahaan nonkeuangan yang terdaftar di Bursa Efek Indonesia selama 5 tahun berturut-turut, dari tahun 2013 sampai dengan tahun 2017. Metode pemilihan sampel yang digunakan adalah purposive sampling. Sampel penelitian adalah 52 perusahaan non-keuangan yang terdaftar di Bursa Efek Indonesia. Pengujian hipotesis menggunakan model regresi berganda. Hasil penelitian mengindikasikan bahwa economic value added, debt to equity ratio, total assets turnover, net profit margin, dan earnings per share tidak berpengaruh terhadap return saham. Tetapi, market value added, dan return on equity memiliki pengaruh positif terhadap return saham. Sedangkan price to book value memiliki pengaruh negatif terhadap return saham.

Kata kunci: Return saham, economic value added, market value added, kinerja keuangan.

\section{PENDAHULUAN}

Secara umum, perusahaan melakukan analisis laporan keuangan dengan mengukur rasio keuangan secara konvensional dengan tujuan untuk mengukur kinerja keuangannya. Rasio keuangan berfungsi dalam pengambilan keputusan manajemen, tetapi rasio keuangan tidak memberikan jaminan bahwa kinerja perusahaan mencerminkan keadaan 
sesungguhnya (Huda et al. 2015). Analisis rasio keuangan memiliki kelemahan yaitu perusahaan tidak memperhatikan biaya-biaya modal selama menghitung kinerja keuangannya. Cara untuk mengatasi kelemahan tersebut adalah dengan memperdalam dan mengembangkan konsep pengukuran kinerja melalui Economic Value Added (EVA) dan Market Value Added (MVA). Kedua metode ini merupakan standar bagi perusahaan untuk mengukur kinerja keuangan yang mencerminkan keadaan sebenarnya, yaitu melalui pertimbangan biaya modal dan nilai pasar saham.

Berdasarkan artikel Aditiasari (2018) yang dikutip dari situs detik finance, angka IHSG menurun tajam dan menyebabkan perekonomian Indonesia tidak dapat mencapai target. Saat perdagangan preopening, IHSG melemah ke level 6.556,679 dan diikuti dengan penurunan indeks LQ45 menjadi 1.093,824. Pada tanggal 05 Februari 2018, IHSG kembali menguat 6.637,638. Indeks LQ45 ikut menguat ke level 1.114,065. Pada Jakarta Automated Trading System (JATS), IHSG bergerak terus turun ke level $6.537,751$. Bursa sektor juga mengalami penurunan, hanya industri pertambangan yang bertahan di zona hijau. Selain itu, perusahaan non-keuangan yang terdaftar di Bursa Efek Indonesia (BEI), baik manufaktur, dan sebagainya pun ikut terkena dampak penurunan nilai tersebut.

Penelitian ini merupakan pengembangan dari penelitian Huda et al. (2015) yang menggunakan enam variabel independen antara lain economic value added, market value added, return on investment, debt to equity ratio, price to book value dan total assets turnover. Sampel yang digunakan dalam penelitian Huda et al. (2015) adalah data dari enam perusahaan minyak kelapa sawit representatif yang terdaftar di Bursa Efek Indonesia (BEI) mulai dari tahun 2009 sampai dengan 2014. Perbedaan penelitian terletak pada penambahan variabel return on equity, net profit margin, earnings per share, dan ukuran perusahaan. Objek penelitian ini adalah perusahaan non-keuangan yang terdaftar di Bursa Efek Indonesia. Periode penelitian ditetapkan 4 tahun, yaitu dari tahun 2014 sampai dengan tahun 2017.

Motivasi peneliti adalah menganalisis faktor-faktor yang mempengaruhi return saham yang dilihat dari kinerja keuangan dan ukuran perusahaan. Tujuan penelitian adalah untuk mendapatkan bukti empiris mengenai pengaruh economic value added, market value added, return on investment, debt to equity ratio, price to book value, total assets turnover, return on equity, net profit margin, earnings per share, dan ukuran perusahaan terhadap return saham.

Penelitian ini disusun dengan urutan penulisan sebagai berikut; Pertama, bagian Pendahuluan yang menguraikan isu dan masalah penelitian, tujuan penelitian, motivasi peneliti, dan organisasi penulisan. Kedua, bagian Rerangka Teoritis dan Pengembangan Hipotesis yang menjelaskan teori induk dan teori atas variabel-variabel yang digunakan dalam penelitian. Ketiga, Metoda Penelitian yang terdiri atas pemilihan sampel, teknik pengumpulan data, definisi operasional dan pengukuran variabel. Keempat, Hasil Penelitian yang menguraikan analisis dan pembahasan dari penelitian ini. Kelima, Penutup yang berisi simpulan, implikasi, keterbatasan penelitian, dan saran untuk penelitian selanjutnya.

\section{Economic Value Added}

Economic value added merupakan alat yang digunakan untuk mengevaluasi aktivitas perusahaan yang dilihat dari perhitungan biaya modal dengan menggunakan rata-rata tertimbang biaya modal (Alexander dan Destriana 2013). Konsep economic value added merupakan cara mengukur profitabilitas operasi yang sesungguhnya. Economic value added digunakan oleh manajer untuk menentukan apakah dalam melaksanakan kegiatan operasionalnya, perusahaan mampu menambah nilai atau tidak, sementara investor 
dapat menggunakan economic value added untuk mengetahui apakah nilai saham akan meningkat apabila perusahaaan mampu menambah nilainya (Brigham dan Houston 2001 dalam Puspitawati dan Supardi 2008).

Hasil penelitian Huda et al. (2015), dan Jamkarani dan Khatiri (2016), menunjukkan bahwa economic value added berpengaruh secara positif terhadap return saham. Economic value added berpengaruh secara positif karena pengukurannya memperhitungkan biaya modal perusahaan. Jika economic value added meningkat, maka dapat disimpulkan bahwa laba yang tersedia dapat digunakan untuk menutupi biaya modal yang telah diinvestasikan.

Sedangkan penelitian yang dilakukan oleh Janitra dan Kesuma (2015), dan Safitri dan Indriyani (2017) menyatakan bahwa economic value added tidak memiliki pengaruh terhadap return saham. Sebagian besar negara di dunia, termasuk di Indonesia masih belum mempraktikkan economic value added, sehingga investor dan perusahaan tidak begitu memperhatikan pengukuran menggunakan economic value added.

$\mathrm{H}_{1}$ : Terdapat pengaruh economic value added terhadap return saham.

\section{Market Value Added}

Market value added merupakan selisih antara harga pasar saham perusahaan dengan nilai nominal dari saham tersebut. Tujuan perusahaan awalnya adalah memperoleh laba sebanyaknya, berpindah menjadi usaha meningkatkan kemakmuran pemegang saham (Kartini dan Hermawan 2008). Jika perusahaan mampu memaksimalkan kemakmuran pemegang saham, maka investor akan berinvestasi dalam perusahaan tersebut. Oleh karena itu, perusahaan meninggalkan aktivitas lamanya, dari meningkatkan penjualan menjadi berfokus untuk menambah nilai perusahaan (Alexander dan Destriana 2013).

Penelitian yang dilakukan oleh Huda et al. (2015) dan Jamkarani dan Khatiri (2016) menunjukkan hasil bahwa market value added berpengaruh secara positif terhadap return saham. Market value added berpengaruh karena return ekspektasi yang akan diterima investor dapat meningkat melalui peningkatan harga saham perusahaan yang jauh dari nilai ekuitasnya. Semakin tinggi harga saham, return ekspektasi yang diperoleh semakin besar.

Menurut penelitian Kartini dan Hermawan (2008), dan Cahyadi dan Darmawan (2016), market value added tidak berpengaruh terhadap return saham. Ini membuktikan bahwa nilai pasar yang lebih besar dibandingkan nilai book value tidak mempengaruhi harga pasar dan return saham secara keseluruhan yang disebabkan oleh perbedaan nilai yang ekstrem antara nilai pasar ekuitas dengan nilai nominalnya.

$\mathrm{H}_{2}$ : Terdapat pengaruh market value added terhadap return saham.

\section{Debt to Equity Ratio}

Debt to equity ratio mengukur proporsi dari total kewajiban pada modal yang digunakan untuk mendanai aset-aset perusahaan. Semakin tinggi rasio ini, maka semakin besar penggunaan utang dalam perusahaan (Gitman dan Zutter 2015, 126). Debt to equity ratio adalah rasio solvabilitas yang menganalisis apakah perusahaan dapat melunasi segala kewajibannya serta melihat seberapa besar modal yang dimiliki oleh perusahaan (Purwitajati dan Putra 2016).

Hasil penelitian yang dilakukan oleh Setiyono dan Amanah (2016), Purwitajati dan Putra (2016), dan Anisa (2015) menunjukkan bahwa debt to equity ratio berpengaruh secara positif terhadap return saham. Debt to equity ratio menunjukkan bahwa perusahaan menggunakan utang untuk membiayai investasinya (Setiyono dan Amanah 2016). $\mathrm{H}_{3}$ : Terdapat pengaruh debt to equity ratio terhadap return saham. 


\section{Price to Book Value}

Price to book value merupakan rasio pasar (market ratio) yang digunakan untuk mengukur kinerja harga pasar saham terhadap nilai buku dari ekuitas perusahaan. Semakin tinggi rasio price to book value, menunjukkan bahwa perusahaan mampu menambah nilai melalui peningkatan harga pasarnya (Sari 2013 dalam Najmiyah et al. 2014). Hal ini sesuai dengan teori sinyal bahwa nilai perusahaan digunakan sebagai sinyal oleh investor, sehingga investor dapat mengetahui besarnya nilai perusahaan. Semakin tinggi nilai perusahaan, maka sinyal tersebut akan menarik investor untuk berinvestasi. Dengan demikian, harga saham dan return saham akan naik (Najmiyah et al. 2014).

Hasil penelitian yang dilakukan oleh Huda et al. (2015), Arista dan Astohar (2012), dan Andansari et al. (2016) menjelaskan price to book value memiliki pengaruh positif terhadap return saham. Peningkatan price to book value ini menunjukkan bahwa kinerja saham baik melalui nilai pasar yang melebihi nilai buku ekuitasnya, sehingga investor dapat mengambil keputusan investasi dengan membeli saham perusahaan tersebut. Jadi dapat disimpulkan bahwa jika perusahaan menunjukkan kinerja keuangan yang baik, maka akan berdampak pada peningkatan return saham (Julianto dan Susanto 2017, Arista dan Astohar 2012).

$\mathrm{H}_{4}$ : Terdapat pengaruh price to book value terhadap return saham.

\section{Total Assets Turnover}

Total assets turnover mengindikasikan efisiensi dengan mana perusahaan menggunakan aset-asetnya untuk menghasilkan penjualan (Gitman dan Zutter 2015, 123). Total assets turnover mengukur seberapa efisien perusahaan menggunakan asetnya untuk menghasilkan penjualan (Weygandt et al. 2015, 723). Total assets turnover merupakan rasio yang digunakan untuk mengukur apakah perusahaan mampu mengelola aset-asetnya dengan efisien dalam kegiatan operasional, serta mengukur perputaran semua aset yang dimiliki perusahaan. Total assets turnover yang tinggi mengindikasikan bahwa manajer perusahaan mampu mengelola perputaran aset yang kemudian akan menghasilkan pendapatan atau penjualan, sehingga keuntungan yang diperoleh pun besar (Puspitasari et al. 2017).

Menurut hasil penelitian oleh Huda et al. (2015), Rosiana et al. (2014), dan Khotimah dan Murtaqi (2015), total assets turnover berpengaruh secara positif terhadap return saham. Semakin tinggi nilai total assets turnover menunjukkan semakin tinggi nilai penjualan yang diperoleh perusahaan sebanding dengan jumlah aset yang dimiliki dan yang dikelola dengan efisien. Dengan nilai penjualan yang tinggi dan pengelolaan aset yang efisien memberikan keyakinan investor terhadap perusahaan untuk memperoleh laba yang tinggi pula (Rosiana et al. 2014).

$\mathrm{H}_{5}$ : Terdapat pengaruh total assets turnover terhadap return saham.

\section{Return on Equity}

Return on Equity (ROE) mengukur return yang diterima pada investasi saham biasa dalam suatu perusahaan. Secara umum, pemilik lebih baik memiliki return yang lebih tinggi (Gitman dan Zutter 2015, 130). Rasio ini mengukur profitabilitas dari pandangan pemegang saham biasa. Rasio ini menunjukkan berapa laba bersih yang diterima perusahaan dari tiap jumlah yang diinvestasikan oleh pemilik (Weygandt et al. 2015, 724). Hasil penelitian yang dilakukan oleh Antara et al. (2014), Legiman et al. (2015), Andansari et al. (2016), serta Mahardika dan Artini (2017) menunjukkan bahwa return on equity berpengaruh secara positif terhadap return saham. Hal ini dapat membuktikan bahwa meningkatnya nilai return on equity maka mempengaruhi peningkatan return yang diterima investor. Hal ini disebabkan oleh karena return on equity yang tinggi 
menunjukkan bahwa perusahaan mampu mengelola modalnya dengan efektif dan efisien untuk melanjutkan kegiatan operasionalnya (Julianto dan Susanto 2017, Carlo 2014).

$\mathrm{H}_{6}$ : Terdapat pengaruh return on equity terhadap return saham.

\section{Net Profit Margin}

Menurut Gitman dan Zutter $(2015,129)$, net profit margin menganalisis secara proporsional tiap penjualan setelah semua beban, baik bunga, pajak, maupun dividen saham preferen telah dikurangkan. Semakin tinggi net profit margin perusahaan, maka semakin baik. Profit margin mengukur persentase tiap mata uang penjualan yang menghasilkan laba bersih (Weygandt et al. 2015, 723).

Hasil penelitian menurut Putra dan Kindangen (2016), dan Bakkara et al. (2017) menunjukkan net profit margin memiliki pengaruh positif terhadap return saham. Ini menjelaskan bahwa perusahaan akan memenuhi harapan investor dengan cara meningkatkan penjualan dan keuntungannya agar investor mau membeli saham perusahaan tersebut. Investor potensial juga dapat melihat kinerja keuangan perusahaan baik dan menghasilkan laba (Sari dan Sugiyono 2016).

$\mathrm{H}_{7}$ : Terdapat pengaruh net profit margin terhadap return saham.

\section{Earnings per Share}

Earnings per Share (EPS) adalah laba yang dibagi dengan jumlah saham yang beredar (Kidwell et al. 2011, 287). Earnings per share mewakili jumlah yang diterima selama periode pada tiap jumlah saham yang beredar dari saham biasa (Gitman dan Zutter 2015, 130). Earnings per share (EPS) adalah rasio laba bersih yang dihitung untuk setiap jumlah saham yang beredar. Pengukuran laba bersih yang diterima per lembar saham menyediakan dasar perspektif yang berguna untuk menentukan profitabilitas (Weygandt et al. 2015, 725).

Hasil penelitian yang dilakukan oleh Sari dan Sugiyono (2016), Puspitasari et al. (2017), dan Janitra dan Kesuma (2015) menunjukkan bahwa earnings per share berpengaruh secara positif terhadap return saham. Hasil ini menjelaskan semakin besar rasio ini maka pendapatan pun semakin besar serta menjelaskan tingkat keuntungan yang besar pula. Peningkatan harga saham membuat return saham yang diperoleh investor juga meningkat (Setiyono dan Amanah 2016).

$\mathrm{H}_{8}$ : Terdapat pengaruh earnings per share terhadap return saham.

\section{METODE PENELITIAN}

Populasi dalam penelitian ini adalah perusahaan non-keuangan yang terdaftar di Bursa Efek Indonesia selama periode 20132017. Metode pemilihan sampel yang digunakan adalah purposive sampling. Terdapat 52 perusahaan dari total 391 perusahaan nonkeuangan yang secara konsisten terdaftar di Bursa Efek Indonesia dari tahun 2013-2017. Jumlah keseluruhan sampel data yang diperoleh berdasarkan periode penelitian 2014-2017 adalah sebanyak 208 data. Prosedur pemilihan sampel dapat dilihat pada tabel 1. 
Tabel 1 Prosedur Pemilihan Sampel Penelitian

\begin{tabular}{|c|c|c|c|}
\hline No. & Keterangan & Perusahaan & Data \\
\hline 1. & $\begin{array}{l}\text { Perusahaan non-keuangan yang secara konsisten } \\
\text { terdaftar di Bursa Efek Indonesia dari tahun } 2013 \\
\text { sampai 2017. }\end{array}$ & 391 & 1.564 \\
\hline 2. & $\begin{array}{l}\text { Perusahaan non-keuangan yang tidak menerbitkan } \\
\text { laporan keuangan yang berakhir pada tanggal } 31 \\
\text { Desember selama periode penelitian. }\end{array}$ & (15) & (60) \\
\hline 3. & $\begin{array}{l}\text { Perusahaan non-keuangan yang tidak menerbitkan } \\
\text { laporan keuangan dalam satuan mata uang Rupiah } \\
\text { selama periode penelitian. }\end{array}$ & (72) & (288) \\
\hline 4. & $\begin{array}{l}\text { Perusahaan non-keuangan yang tidak konsisten } \\
\text { memperoleh laba selama periode penelitian. }\end{array}$ & (123) & (492) \\
\hline 5. & $\begin{array}{l}\text { Perusahaan non-keuangan yang sahamnya tidak aktif } \\
\text { diperdagangkan selama periode penelitian berdasarkan } \\
\text { surat edaran BEJ No. SE-03/BEJ/II-1/1994. }\end{array}$ & (30) & $(120)$ \\
\hline \multirow[t]{2}{*}{6.} & $\begin{array}{l}\text { Perusahaan yang melakukan corporate action dari } \\
\text { tahun } 2013 \text { sampai } 2017 \text {. }\end{array}$ & (99) & (396) \\
\hline & Total perusahaan yang memenuhi kriteria & 52 & 208 \\
\hline
\end{tabular}

Sumber: Bursa Efek Indonesia.

Return saham merupakan tingkat pengembalian yang berasal dari selisih harga saham periode tahun depan dengan harga saham periode saat ini (Huda et al. 2015). Return saham diukur dengan rumus (Huda et al. 2015):

Keterangan:

$$
P_{a i}=\frac{P_{i . t}-P_{i . t-1}}{P_{i . t-1}}
$$

Pai $=$ Return saham

Pi.t = Harga saham penutupan perusahaan $\mathrm{i}$ pada periode $t$.

Pi.t-1 = Harga saham penutupan perusahaan i pada priode t-1.

Economic value added merupakan selisih laba bersih operasi setelah pajak dengan biaya modal yang dihitung dengan cara rata-rata biaya modal tertimbang. Economic value added diukur berdasarkan skala nominal dengan rumus (Dwitayanti 2005 dalam Dwihandoko 2017):

$$
E V A=\text { NOPAT }- \text { CC }
$$

Keterangan:

$\mathrm{EVA}=$ Economic Value Added

$$
\begin{aligned}
\text { NOPAT } & =\text { Net Operating Profit after Tax } \\
& =\text { Profit after Tax }+ \text { Interest Expense } \\
\text { CC } & =\text { Capital Charges } \\
& =\text { Invested Capital } x \text { WACC } \\
& =[(\text { Total Debt }+ \text { Total Equity })-\text { Short- }
\end{aligned}
$$

term Debt] x WACC

$$
\begin{aligned}
\text { WACC }= & \text { Weighted-Average Cost of Capital } \\
= & {[(\mathrm{D} \times \mathrm{rd}) \times(1-\text { Tax })+(\text { E } \times \text { re })] } \\
= & \{[(\text { Total Debt / (Total Debt }+ \text { Total } \\
& \text { Equity })] \times[(\text { Interest } \\
& \text { Expense / Total Debt })] \times[1-(\text { Income } \\
& \text { Tax Expense / Profit Before Tax })]\}+ \\
& \{[(\text { Total Equity / (Total Debt }+ \text { Total } \\
& \text { Equity })] \times[1 / \text { PER }]\}
\end{aligned}
$$

Market value added merupakan perbedaan jumlah kas, baik utang maupun ekuitas dimiliki oleh investor yang berkontribusi pada nilai kas yang diharapkan. Market value added diukur berdasarkan skala nominal dengan menggunakan rumus (Huda et al. 2015): MVA = Equity Market Value - Equity Book Value 
Keterangan:

Equity Market Value $=$ Number of shares $x$

$$
\text { Price/shares. }
$$

Equity Book Value $=$ Number of shares $x$ Par

$$
\text { Value/shares. }
$$

Debt to equity ratio merupakan rasio yang membandingkan total utang terhadap total ekuitas yang dimiliki perusahaan. Rasio ini diukur dengan menggunakan rumus (Huda et al. 2015):

$$
\text { DER }=\frac{\text { Total Debt }}{\text { Total Equity }}
$$

Price to book value merupakan rasio pasar yang digunakan untuk mengukur kinerja nilai pasar saham terhadap nilai bukunya. Rasio ini diukur dengan menggunakan rumus (Huda et al. 2015):

$$
\mathrm{PBV}=\frac{\mathrm{P}_{\mathrm{s}}}{\mathrm{BVS}}
$$

Keterangan;

$\mathrm{P}_{\mathrm{s}} \quad=$ Price (Closing Price)

BVS = Total Equity / Number of Outstanding Shares

Total assets turnover merupakan salah satu rasio aktivitas yang mengukur perputaran tingkat penjualan terhadap total aset suatu perusahaan. Rasio ini diukur dengan menggunakan rumus (Huda et al. 2015):

$$
\text { TATO }=\frac{\text { Sales }}{\text { Total Assets }}
$$

Return on equity menganalisis apakah perusahaan mampu mendapatkan laba untuk para pemegang saham biasa untuk mengetahui berapa pengembalian untuk setiap berapa rupiah modal dari pemilik. Rasio ini diukur dengan menggunakan rumus (Sugiarti et al. 2015):

$$
\text { ROE }=\frac{\text { Profit after tax }}{\text { Total Equity }}
$$

Net profit margin menganalisis apakah perusahaan mampu menghasilkan laba pada suatu tingkat penjualan. Rasio ini diukur dengan menggunakan rumus (Mahmudah dan Suwitho 2016):

$$
\text { NPM }=\frac{\text { Profit after tax }}{\text { Sales }}
$$

Earnings per share digunakan untuk menganalisis kesuksesan perusahaan dalam memperoleh keuntungan per lembar saham untuk tiap pemegang saham. Pengukuran rasio ini menggunakan rumus (Setiyono dan Amanah 2016):

$$
\text { EPS }=\frac{\text { Profit after tax }}{\text { Number of Oustanding Shares }}
$$

Persamaan regresi berganda dalam penelitian dapat dituliskan sebagai berikut:

$R S=\beta_{0}+\beta_{1}$ EVA $+\beta_{2} M V A+\beta_{3}$ DER $+\beta_{4}$ PBV $+\beta_{5}$ TATO $+\beta_{6} \mathrm{ROE}+\beta_{7} \mathrm{NPM}+\beta_{8} \mathrm{EPS}+\varepsilon$ 
HASIL PENELITIAN

Tabel 2 Hasil Uji Statistik Deskriptif

\begin{tabular}{ccrrrr}
\hline Variabel & N & Minimum & \multicolumn{1}{c}{ Maximum } & \multicolumn{1}{c}{ Mean } & \multicolumn{1}{c}{$\begin{array}{c}\text { Std. } \\
\text { Deviation }\end{array}$} \\
\hline RS & 208 & $-0,875294$ & 9,800000 & 0,187426 & 0,847658 \\
EVA & 208 & -882257 & 7071426 & 481756903 & 1327443 \\
& & 874818 & 285547 & 164,37 & 451065,820 \\
MVA & 208 & -609429 & 426440700 & 15236279 & 49155206 \\
& & 846628 & 000000 & 960280,90 & 732809 \\
DER & 208 & 0,082051 & 20,429673 & 1,080268 & 1,560338 \\
PBV & 208 & 0,204145 & 274,820713 & 4,403658 & 21,084918 \\
TATO & 208 & 0,043995 & 3,747196 & 1,012952 & 0,709558 \\
ROE & 208 & 0,000374 & 8,910532 & 0,189553 & 0,647409 \\
NPM & 208 & 0,001362 & 0,688703 & 0,104829 & 0,110274 \\
EPS & 208 & 0,312970 & 4030,661280 & 268,265293 & 581,540671 \\
\hline
\end{tabular}

Sumber: Hasil Pengolahan Data SPSS 25

Tabel 3 Hasil Uji t

\begin{tabular}{lrc}
\hline Variabel & \multicolumn{1}{c}{ B } & Sig. \\
\hline Konstanta & 0,095 & 0,575 \\
EVA & $-3,003 \mathrm{E}-13$ & 0,083 \\
MVA & $1,379 \mathrm{E}-14$ & 0,025 \\
DER & $-0,116$ & 0,163 \\
PBV & $-0,097$ & 0,005 \\
TATO & 0,060 & 0,592 \\
ROE & 3,268 & 0,002 \\
NPM & $-0,655$ & 0,416 \\
EPS & 0,000 & 0,431 \\
\hline
\end{tabular}

\section{Sumber: Hasil Pengolahan Data SPSS 25}

Statistik deskriptif dan hasil uji t penelitian ini terdapat pada tabel 2 dan tabel 3 (lampiran). Hasil pengujian $\mathrm{Ha}_{1}$ menunjukkan nilai signifikansi economic value added (EVA) sebesar 0,083 lebih besar dari 0,05, sehingga $\mathrm{Ha}_{1}$ tidak dapat diterima. Tidak terdapat pengaruh economic value added (EVA) terhadap return saham. Hasil ini konsisten dengan penelitian yang dilakukan oleh Janitra dan KesumSafitri dan Indriyani (2017).

Hasil pengujian $\mathrm{Ha}_{2}$ menunjukkan nilai signifikansi market value added (MVA) sebesar 0,025 lebih kecil dari 0,05 , sehingga $\mathrm{Ha}_{2}$ dapat diterima. Terdapat pengaruh market value added (MVA) terhadap return saham. Hasil ini konsisten dengan penelitian yang dilakukan oleh Huda et al. (2015), serta Jamkarani dan Khatiri (2016).

Hasil pengujian $\mathrm{Ha}_{3}$ menunjukkan nilai signifikansi debt to equity ratio (DER) sebesar 0,163 lebih besar dari 0,05 , sehingga $\mathrm{Ha}_{4}$ tidak dapat diterima. Tidak terdapat pengaruh debt to equity ratio (DER) terhadap return saham. Hasil ini konsisten dengan penelitian yang dilakukan oleh Sugiarti et al. (2015) dan Puspitasari et al. (2017). 
Hasil pengujian $\mathrm{Ha}_{4}$ menunjukkan nilai signifikansi price to book value (PBV) sebesar 0,005 lebih kecil dari 0,05 , sehingga $\mathrm{Ha}_{5}$ dapat diterima. Terdapat pengaruh price to book value (PBV) terhadap return saham. Hasil ini konsisten dengan penelitian yang dilakukan oleh Huda et al. (2015) Andasari et al. (2016).

Hasil pengujian $\mathrm{Ha}_{5}$ menunjukkan nilai signifikansi total assets turnover (TATO) sebesar 0,592 lebih besar dari 0,05, sehingga $\mathrm{Ha}_{6}$ tidak dapat diterima. Tidak terdapat pengaruh total assets turnover (TATO) terhadap return saham. Hasil ini konsisten dengan penelitian yang dilakukan oleh Puspitasari et al. (2017).

Hasil pengujian $\mathrm{Ha}_{6}$ menunjukkan nilai signifikansi return on equity (ROE) sebesar 0,002 lebih kecil dari 0,05, sehingga $\mathrm{Ha}_{7}$ dapat diterima. Terdapat pengaruh return on equity (ROE) terhadap return saham. Hasil ini konsisten dengan penelitian yang dilakukan oleh Andasari et al. (2016), serta Mahardika dan Artini (2017).

Hasil pengujian $\mathrm{Ha}_{7}$ menunjukkan nilai signifikansi net profit margin (NPM) sebesar 0,416 lebih besar dari 0,05 , sehingga $\mathrm{Ha}_{8}$ tidak dapat diterima. Tidak terdapat pengaruh net profit margin (NPM) terhadap return saham. Hasil ini konsisten dengan penelitian yang dilakukan oleh Mahmudah dan Suwitho (2016) dan Mahardika dan Artini (2017).
Hasil pengujian $\mathrm{Ha}_{8}$ menunjukkan nilai signifikansi earnings per share (EPS) sebesar 0,431 lebih besar dari 0,05 , sehingga Hag tidak dapat diterima. Tidak terdapat pengaruh earnings per share (EPS) terhadap return saham. Hasil ini konsisten dengan penelitian yang dilakukan oleh Sugiarti et al. (2015) dan Risdiyanto dan Suhermin (2016).

\section{PENUTUP}

Berdasarkan hasil penelitian terdapat indikasi bahwa economic value added, debt to equity ratio, total assets turnover, net profit margin, dan earnings per share tidak berpengaruh terhadap return saham. Tetapi, market value added, dan return on equity memiliki pengaruh positif terhadap return saham. Sedangkan price to book value memiliki pengaruh negatif terhadap return saham. Keterbatasan penelitian ini adalah data tidak berdistribusi normal, serta banyaknya variabel independen yang tidak berpengaruh terhadap return saham. Berdasarkan keterbatasan tersebut, rekomendasi yang dianjurkan adalah menambah data penelitian untuk mengatasi masalah data tidak berdistribusi normal, serta menambah variabel-variabel seperti residual income, price earning ratio, firm growth, dan earnings yang mungkin berpengaruh terhadap return saham.

\section{REFERENCES:}

Aditiasari, Dana. 05 Februari 2018. Pertumbuhan Ekonomi RI Tak Capai Target, IHSG Negatif. Detikfinance, (https://finance.detik.com/bursa-danvalas/d-3850314/pertumbuhan-ekonomi-ri-tak-capai-target-ihsgnegatif, 06 Februari 2018).

Alexander, Nico dan Nicken Destriana. 2013. Pengaruh Kinerja Keuangan Terhadap Return Saham. Jurnal Bisnis dan Akuntansi, 15(2), 123-132.

Andansari, Neni Awika, Kharis Raharjo, dan Rita Andini. 2016. Pengaruh Return on Equity (ROE), Price Earning Ratio (PER), Total Asset Turnover (TATO) dan Price to Book Value (PBV) Terhadap Return Saham. Journal of Accounting, 02(2)

Anisa, Nesa. 2015. Analisis Faktor-faktor yang Mempengaruhi Return Saham (Studi Kasus pada Perusahaan Sub Sektor Automotive and Components yang Terdaftar di Bursa Efek Indonesia Periode 2010-2014). Perbanas Review, 1(1), 72-86. 
Antara, Stefanus, Jantje Sepang, dan Ivonne S. Saerang. 2014. Analisis Rasio Likuiditas, Aktivitas, dan Profitabilitas Terhadap Return Saham Perusahaan Wholesale yang Terdaftar di Bursa Efek Indonesia. Jurnal EMBA, 2(3), 902-911.

Arista, Desy dan Astohar. 2012. Analisis Faktor-faktor yang Mempengaruhi Return Saham (Kasus pada Perusahaan Manufaktur yang Go Public di BEI Periode Tahun 2005-2009). Jurnal IImu Manajemen dan Akuntansi Terapan, 3(1), 1-15.

Bakkara, Yosep William, Farida Titik, dan Dewa Putra Khrisna. 2017. Pengaruh Net Profit Margin, Debt to Equity Ratio, dan Earnings Per Share pada Perusahaan Manufaktur Sub Sektor Otomotif yang Terdaftar di Bursa Efek Indonesia Tahun 2011-2015. E-Proceeding of Management, 4(1).

Cahyadi, Hari, dan Akhmad Darmawan. 2016. Pengaruh Economic Value Added, Market Value Added, Residual Income, Earnings, dan Arus Kas Operasi Terhadap Return Saham (Studi Empiris pada Perusahaan LQ45). Jurnal Manajemen dan Bisnis Media Ekonomi, XVI(1), 176- 195.

Carlo, Michael Aldo. 2014. Pengaruh Return on Equity, Dividend Payout Ratio, dan Price to Earnings Ratio pada Return Saham. E-Jurnal Akuntansi Universitas Udayana, 7(1), 150-164.

Copeland, Thomas E., J. Fred Weston, and Kuldeep Shastri. 2005. Financial Theory and Corporate Policy, 4th Edition. United States: Pearson Addison Wesley.

Dwitayanti, Yevi. 2005. Analisis Pengaruh Economic Value Added (EVA) Terhadap Market Value Added pada Industri Manufaktur di Bursa Efek Jakarta. Jurnal Manajemen dan Keuangan, 3(1), 59-73.

Gitman, Lawrence J., and Chad J. Zutter. 2015. Principles of Managerial Finance, 14th Edition. England: Pearson.

Huda, Ghulam Nurul, Bonar M. Sinaga, dan Trias Andati. 2015. The Influence of Corporate Financial Performance on Share Return. Indonesian Journal of Business and Entrepreneurship, 1(3), 177-185.

Jamkarani, Reza Gholami dan Mohammad Khatiri. 2016. The Impact of Performance Evaluation Criteria on Annual Stock Return in Different Stages on Firm's Life Cycle. International Journal of Business Quantitative Economics and Applied Management Research, 3(2), 24-34.

Janitra, Putu Vito Veda dan I Ketut Wijaya Kesuma. 2015. Pengaruh EPS, ROI, dan EVA Terhadap Return Saham Perusahaan Otomotif di BEI. E-Jurnal Manajemen Unud, 4(7), 1831-1844.

Julianto, T, \& Susanto, Y.K. 2017. Value Added Intellectual Coefficient Dan Stock Return. Jurnal Wira Ekonomi Mikroskil: JWEM, 7(1), 79-88.

Kartini dan Gatot Hermawan. 2008. Economic Value Added dan Market Value Added Terhadap Return Saham. Jurnal Keuangan dan Perbankan, 12(3), 355-368.

Khotimah, Khusnul, dan Isrochmani Murtaqi. 2015. The Fundamental Analysis of Indonesian Stock Return (Case Study: Listed Public Companies in SubSector Food and Beverage for the Period 2003-2012). Journal of Business and Management, 4(1), 2015: 95-104.

Kidwell, David S., David W. Blackwell, David A. Whidbee, and Richard W. Sias. 2013. Financial Institutions, Markets, and Money, 11th Edition. New Jersey: John Wiley Sons.

Legiman, Fachreza Muhammad, Parengkuan Tommy, dan Victoria Untu. 2015. Faktor-faktor yang Mempengaruhi Return Saham pada Perusahaan Agroindustry yang Terdaftar di Bursa Efek Indonesia Periode 20092012. Jurnal EMBA, 3(3), 382-392.

Mahardika, I Nyoman Febri, dan Luh Gede Sri Artini. 2017. Pengaruh Rasio Pasar dan Rasio Profitabilitas Terhadap Return Saham Perusahaan di Bursa Efek Indonesia. E-Jurnal Manajemen Unud, 6(4), $1877-$ 1905.

Mahmudah, Umrotul dan Suwitho. 2016. Pengaruh ROA, Firm Size, dan NPM Terhadap Return Saham pada Perusahaan Semen. Jurnal IImu dan Riset Manajemen, 5(1), 1-15.

Najmiyah, Edy Sujana, dan Ni Kadek Sinarwati. 2014. Pengaruh Price to Book Value (PBV), Price Earning Ratio (PER) dan Debt to Equity Ratio (DER) Terhadap Return Saham pada Industri Real Estate dan Property yang Terdaftar di Bursa Efek Indonesia Periode 2009-2013. E-Journal S1 Ak Universitas Pendidikan Ganesha Jurusan Akuntansi Program S1, 2(1).

Purwitajati, Endah dan I Made Pande Dwiana Putra. 2016. Pengaruh Debt to Equity Ratio pada Return Saham dengan Ukuran Perusahaan sebagai Pemoderasi. E-Jurnal Akuntansi Universitas Udayana, 15(2). 
Puspitadewi, Cokorda Istri Indah dan Henny Rahyuda. 2016. Pengaruh DER, ROA, PER dan EVA Terhadap Return Saham pada Perusahaan Food and Beverages di BEl. E-Jurnal Manajemen Unud, 5(3).

Puspitasari, Putrilia Dwi, Nyoman Trisna Herawati, dan Ni Luh Gede Erni Sulindawati. 2017. Pengaruh Ukuran Perusahaan, Total Asset Turnover, Return on Asset, Current Ratio, Debt to Equity Ratio, Dan Earning per Share Terhadap Return Saham Syariah pada Perusahaan Perdagangan, Jasa, dan Investasi Yang Terdaftar Di Indonesia Sharia Stock Index (ISSI) Periode 2012-2015. E-Journal S1 Ak Universitas Pendidikan Ganesha Jurusan Akuntansi Program S1, 7(1).

Puspitawati, Lilis dan Deddy Supardi. 2008. Pengaruh Return on Investment dan Economic Value Added pada Return Saham Perusahaan Manufaktur. Trikonomika, 7(2).

Putra, Ferdinan Eka dan Paulus Kindangen. 2016. Pengaruh Return on Asset (ROA), Net Profit Margin (NPM), dan Earnings per Share (EPS) Terhadap Return Saham Perusahaan Makanan dan Minuman yang Terdaftar di Bursa Efek Indonesia (Periode 2010-2014). Jurnal EMBA, 4(4).

Rosiana, Rita, Wulan Retnowati, dan Hendro. 2014. Pengaruh Rasio Profitabilitas, Rasio Aktivitas, Rasio Pasar, Firm Size, Tingkat Suku Bunga, dan Nilai Tukar Terhadap Return Saham (Studi Empiris pada Perusahaan Makanan dan Minuman di Bursa Efek Indonesia Periode 2008-2011). Esensi Jurnal Bisnis dan Manajemen, 4(1), 79-91.

Safitri, Tri Melisa, dan Henni Indriyani. 2017. Pengaruh Kinerja Keuangan dan Risiko Sistematis Terhadap Return Saham pada Perusahaan Farmasi di BEI. Seminar Hasil Penelitian FEB (Maret), 128-138.

Sari, Latipah Retna dan Sugiyono. 2016. Pengaruh NPM, ROE, EPS Terhadap Return Saham pada Perusahaan Farmasi di BEI. Jurnal IImu dan Riset Manajemen, 5(12).

Setiyono, Erik dan Lailatul Amanah. 2016. Pengaruh Kinerja Keuangan dan Ukuran Perusahaan Terhadap Return Saham. Jurnal IImu dan Riset Akuntansi, 5(5), 1-17.

Sugiarti, Surachman, dan Siti Aisjah. 2015. Pengaruh Kinerja Keuangan Perusahaan Terhadap Return Saham (Studi pada Perusahaan Manufaktur yang Terdaftar di Bursa Efek Indonesia). Jurnal Aplikasi Manajemen (JAM), 13(2), 282-298.

Weygandt, Jerry J., Paul D. Kimmel, and Donald E. Kieso. 2015. Financial Accounting IFRS Edition, 3e Edition. Hoboken: John Wiley and Sons. 
